\title{
NOWADAYS: THE ROLE OF INTERNET FOR PROPAGATION AND PROLIFERATION OF MUSIC
}

\author{
Deepak Kumar Mittal \\ Raja Mansingh Tomar Music and Arts University, Gwalior
}

In present day internet play a very important role for propagation and proliferation of music in India and world-wide. With the help of internet media we can get each and every information about the music at home. Many websites and softwares are available on internet browsing for music searching, watching, listening, reading and learning.

Google search are best source for searching and type documents of music, YouTube (youtube is a video-sharing website), Skype (Skype is a tele communications application software that specializes in providing video chat and voice calls from computers via the Internet, Online radio (All major Indian and others FM radio stations ready for you to enjoy music and much more), $E$ Journals (Electronic journals are scholarly journals or intellectual magazines that can be accessed via electronic transmission. In practice, this means that they are usually published on the Web), Online and Downloading websites, Social network websites (for exchange messages, post status updates and photos, share videos and receive notifications when others update their profiles, Marketing websites for purchasing music products and accessories

The conclusion of this study, Internet is very beneficial and provides us the facility to gain our music knowledge in Indian and other languages. We can easily learn a number of musical disciplines in our national and other languages at home sitting.

Internet has been the most useful technology of the modern times which helps us not only in our daily lives, but also our personal and professional lives developments. The internet helps us achieve this in several different ways.

For the students and educational purposes the internet is widely used to gather information so as to do the research or add to the knowledge of any sort of subject they have. Even the business personals and the professions like doctors, access the internet to filter the necessary information for their use. The internet is therefore the largest encyclopedia for everyone, in all age categories. The internet has served to be more useful in maintaining contacts with friends and relatives who live abroad permanently. The easiest communication means like the internet chatting systems and the emails are the best and the most common for the maintaining contacts with the people around the world.

Not to forget internet is useful in providing with most of the fun these days. May it be all the games, and networking conferences or the online movies, songs, dramas and quizzes, internet has provided the users with a great opportunity to eradicate the boredom from their lives. 


\section{INTERNATIONAL JOURNAL Of RESEARCH -GRANTHAALAYAH

Internet is also used to upgrade the internet and use special software to work on the projects and documentation works as the internet enables the user to download a myriad of different software for a variety of different purposes, making it much easier than buying the costly software cds.

\section{GOOGLE SEARCH:}

Google Search, commonly referred to as Google Web Search or just Google, is a web search engine owned by Google Inc. It is the most-used search engine on the World Wide Web,[1] handling more than three billion searches each day.[2] The main purpose of Google Search is to hunt for text in publicly accessible documents offered by web servers, as opposed to other data, such as image or database search. It was originally developed by Larry Page and Sergey Brin in 1997. Google Search provides several features beyond searching for words.[3]

\section{YOU TUBE:}

YouTube is a video-sharing website headquartered in San Bruno, California. The service was created by three former PayPalemployees in February 2005 and has been owned by Google since late 2006.[4] The site allows users to upload, view, and share videos, and it makes use of Adobe Flash Video and HTML5 technology to display a wide variety of user-generated and corporate media video. Available content includes video clips, TV clips, music videos, and other content such as video blogging, short originalvideos, and educational videos.

Most of the content on YouTube has been uploaded by individuals, but media corporations including CBS, the BBC, Vevo, Hulu, and other organizations offer some of their material via YouTube, as part of the YouTube partnership program.[5] Unregistered users can watch videos, and registered users can upload videos to their channels. Videos considered to contain potentially offensive content are available only to registered users affirming themselves to be at least 18 years old. YouTube, LLC was bought by Google for US\$1.65 billion in November 2006 and now operates as a Google subsidiary.[6]

\section{SKYPE:}

Skype /'skaip/ is a telecommunications application software that specializes in providing video chat and voice calls from computers, tablets and mobile devices via the Internet to other devices or telephones/smartphones.[7] Users can also sendinstant messages, exchange files and images, send video messages and create conference calls. Skype is available todownload onto computers running Microsoft Windows, Mac or Linux, as well as Android, Blackberry, iOS and Windows Phonesmartphones and tablets. Much of the service is free but users require Skype Credit or a subscription to call landline or mobile numbers. Skype is based on a freemium model.

\section{ONLINE RADIO:}

Internet radio (also web radio, net radio, streaming radio, e-radio, online radio, and webcasting) is an audio service transmitted via theInternet. Broadcasting on the Internet is usually referred to as webcasting since it is not transmitted broadly through wireless means. 


\section{INTERNATIONAL JOURNAL Of RESEARCH -GRANTHAALAYAH

Internet radio involves streaming media, presenting listeners with a continuous stream of audio that typically cannot be paused or replayed, much like traditional broadcast media; in this respect, it is distinct from on-demand file serving. Internet radio is also distinct frompodcasting, which involves downloading rather than streaming.

Internet radio services offer news, sports, talk, and various genres of music-every format that is available on traditional broadcast radiostations.[citation needed] Many Internet radio services are associated with a corresponding traditional (terrestrial) radio station or radio network, although low start-up and ongoing costs have allowed a substantial proliferation of independent Internetonly radio stations

\section{E-JOURNALS:}

Electronic journals, also known as ejournals, e-journals, and electronic serials, are scholarly journals or intellectual magazines that can be accessed via electronic transmission. In practice, this means that they are usually published on the Web. They are a specialized form of electronic document: they have the purpose of providing material for academic research and study, and they are formatted approximately like journal articles in traditional printed journals. Many electronic journals are listed in directories such as the Directory of Open Access Journals, and the articles indexed in bibliographic databases and search engines for the academic discipline concerned.

Some electronic journals are online-only journals; some are online versions of printed journals, and some consist of the online equivalent of a printed journal, but with additional online-only (sometimes video and interactive media) material. [8]

\section{ONLINE AND DOWNLOADING WEBSITES:}

Many websites are available on internet where you will find a wealth of information of music and listening or downloading the Indian Classical Music such as, Musicindiaonline.com, Songspk.com, Myfreemp3.eu, swarganga.com, saptak.com. Darbar.org etc.

\section{SOCIAL NETWORK WEBSITES:}

A social networking service (also social networking site or SNS) is a platform to build social networks or social relations among people who share interests, activities, backgrounds or reallife connections. A social network service (Facebook, Twitter, Linkedin, Google ${ }^{+}$and myspace) consists of a representation of each user (often a profile), his or her social links, and a variety of additional services. Social network sites are web-based services that allow individuals to create a public profile, to create a list of users with whom to share connections, and view and cross the connections within the system.[9]

\section{MARKETING WEBSITES:}

Todays Internet is the best source for marketing any type product or music related materials there is many sites on internet for marketing, from there we have purchased nay type music materials such as music books, instruments, audio and video music CD's and other useful accessories of 


\section{INTERNATIONAL JOURNAL Of RESEARCH -GRANTHAALAYAH

music at service to home delivery. These sites are Olx.com, flipkart.com and other music marketing websites.

\section{DISCUSSIONS AND CONCLUSIONS:}

The internet has transformed the world and the music industry as we know it. Before everybody was hooked up to the World Wide Web, the music scene was a very different place. The advent of social networking also brought a whole new element to the music industry, with MySpace providing a platform for users to follow musicians and discover new bands. YouTube has meant that consumers no longer have to rely on their music videos. Streaming services like Spotify and Pandora give listeners access to any music from anywhere with an internet connection.

So technology and the internet have changed the way we source and listen to music but it has also changed the way music is produced. Where twenty years ago, aspiring artists would rely on corporate bigwigs to listen to their demo disc, the internet has put some power back in their artist's hands.

Thanks to the internet, musicians and singers now have more control over their own fates. They are able to produce their own track, upload it to the internet and promote it accordingly. This not only helps listeners discover them but also producers, helping them to get signed and make it big time.

With internet connectivity continuing to improve and the penetration of smartphones only set to increase, technology and the internet are predicted to maintain a firm hold on how music is consumed, shared and produced. These advancements are welcomed by most as it gives the both the listener and artist both more choice and power.

\section{REFERENCES}

1 Digital Indians: Ben Gomes

2 Jump up $\wedge$ "Almost 12 Billion U.S. Searches Conducted in July". SearchEngineWatch. September 2, 2008.

3 "Search Features". Google. May 2009.

4 Hopkins, Jim (October 11, 2006). "Surprise! There's a third YouTube co-founder".USA Today. Retrieved November 29, 2008.

5 Jump up^ Weber, Tim (March 2, 2007). "BBC strikes Google-YouTube deal". BBC. RetrievedJanuary 17, 2009.

6 Jump up ${ }^{\wedge}$ "Google buys YouTube for $\$ 1.65$ billion". NBC News.

7 Ben Markton (17 April 2014). "Skype". CNET. Retrieved 2 October 2014.

8 Carol Tenopir and Donald King, Towards Electronic Journals. Special Libraries Association, 2000. ISBN 0-87111-507-7.

9 boyd, danah; Ellison, Nicole (2008). "Social Network Sites: Definition, History, and Scholarship". Journal of Computer-Mediated Communication 13: 210-230. 